\title{
The volcanotectonic evolution of Flores Island, Azores (Portugal)
}

\author{
J.M.M. Azevedo *, M.R. Portugal Ferreira \\ Dep. de Ciências da Terra, Universidade de Coimbra, 3000-272 Coimbra, Portugal \\ Received 16 May 2003; accepted 2 March 2006 \\ Available online 11 May 2006
}

\begin{abstract}
From the study and interpretation of the volcanic products and structures of Flores Island, we infer that its volcanic history was dominated by two major periods: (1) proto-insular volcanism, which includes all the submarine and emergent activities; and (2) insular volcanism, consisting exclusively of subaerial eruptions. The first period includes two phases: (1) the oldest (2.2 to $1.5 \mathrm{Ma})$ of shallow submarine volcanism; (2) the youngest (1.0 to $0.75 \mathrm{Ma}$ ) includes emergent volcanism. Throughout the second period, three volcanic stages are recognized: (1) the first one $(0.7$ to $0.5 \mathrm{Ma})$ includes the most voluminous volcanism, balanced between effusive and explosive events; (2) an intermediate stage ( 0.4 to $0.2 \mathrm{Ma})$ that involves a larger number of small-scale feeder centres, with effusive eruptions prevailing; (3) the third stage is the latest volcanic activity of the Island $(\approx 0.003 \mathrm{Ma})$, with strombolian and subsequent phreatic and phreatomagmatic activity centred at four volcanic vents.

From 1.0 Ma to the present, the volcanotectonic development of Flores Island also reflects the operation of two major tectonic processes: (1) a marked volcanotectonic uplift during the first stage (1.0 to $0.55 \mathrm{Ma}$ ); and (2) subsidence, particularly intensive in the island's central area, which led to the subsequent formation of two and perhaps three large calderas during the period 0.55 to $0.4 \mathrm{Ma}$.

(C) 2006 Elsevier B.V. All rights reserved.
\end{abstract}

Keywords: volcanic island; volcanic complex and unit; volcanostratigraphy; subsidence and uplift

\section{Introduction}

Before the mid-1980s, no systematic and comprehensive geological study had been carried out on Flores Island. Our programme started in 1985 with the purpose of improving the 1:25,000 geological map of the island by Zbyszewsky et al. (1968). Initial studies focused on the older volcanic formations (Azevedo et al., 1986; Azevedo, 1988, 1990; Azevedo et al., 1991). Later mapping was extended to the entire island and islandwide volcanostratigraphy was defined. A new 1:15,000 volcanological map includes considerable new geochro-

\footnotetext{
* Corresponding author. Tel.: +351239860 500; fax: +351239860 501.

E-mail address: jazevedo@dct.uc.pt (J.M.M. Azevedo).
}

nologic, petrographic and geochemical data, as well as description of the tectonic and geomorphological histories (Azevedo, 1999, vol. 1; Azevedo and Ferreira, 1999). The volcanostratigraphy and related structural interpretation supported the further studies focused on hydrogeological modelling (Azevedo, 1999, vol. 2).

This paper provides a refined interpretation of the volcanic growth and the structural evolution of Flores, within the framework of the entire Azores region.

\section{Geographic, geotectonic and geochronologic settings}

Flores and Corvo islands constitute the western group of the Azores Archipelago (Fig. 1), which is near the middle of Atlantic Ocean and forms a $600 \mathrm{~km}$-long 


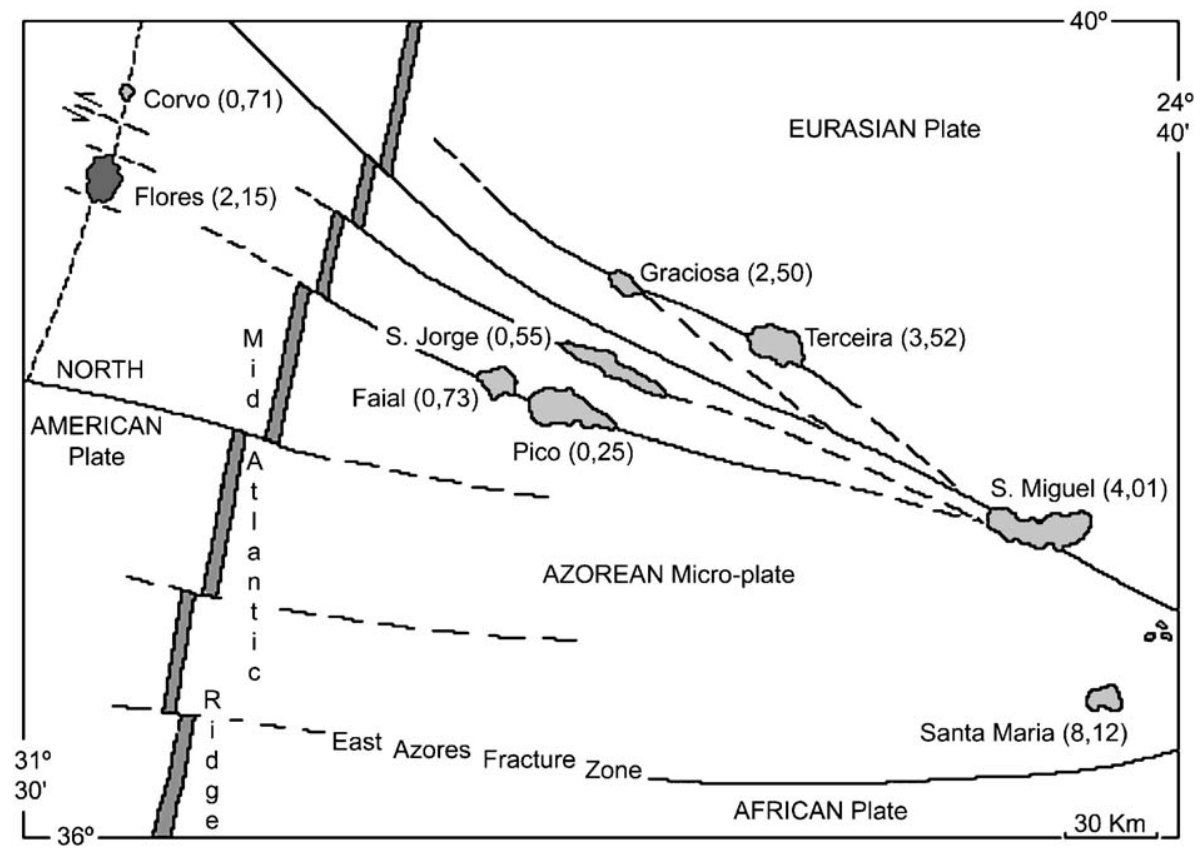

Fig. 1. Geographic and geotectonic setting of Azores Archipelago (adapted from Forjaz, 1988; Baptista et al., 1999) with the oldest radiometric ages (in parentheses; Ma) for each island (geochronological data from Abdel-Monem et al., 1968, 1975; White et al., 1976; Ferraud et al., 1980; Ferreira and Martins, 1983; Feraud et al., 1984; Forjaz, 1988; Azevedo et al., 1991; Azevedo, 1999; Nunes, 1999; Azevedo et al., 2003).

belt trending in a WNW direction. All nine islands (and related seamounts) of this archipelago are within a zone where three lithospheric plates (North American, Eurasian, and African) meet. Most of the islands are located along the fracture-zone extensions of transform faults of the Mid-Atlantic Ridge (MAR). Unlike the other seven islands, Flores and Corvo are on the North American Plate (Fig. 1). The islands of Central Group (Faial, Pico, S. Jorge, Terceira and Graciosa) and Eastern Group (S. Miguel and Santa Maria) are within a transition zone (called the Azorean micro-plate, after Forjaz, 1988) between the Eurasian and African Plates.

Several interpretations and models for the tectonic setting and geodynamic regime of the Azorean region have been proposed mainly on the basis of neotectonic, seismotectonic, GPS data and paleomagnetic interpretations (see for example: Krause and Watkins, 1970; McKenzie, 1972; Machado et al., 1972; Searle, 1980; Hirn et al., 1980; Machado et al., 1983; Buforn et al., 1987; Madeira and Ribeiro, 1990, 1992; Freire Luís et al., 1994; Madeira, 1998; Baptista et al., 1999).

Existing geodynamic models are mainly or exclusively focused on the islands of the Central Group (i.e., Azores microplate) and generally lack a detailed discussion of the tectonic regime for the Western Group islands of Flores and Corvo. This lack reflects the situation that these two islands: (1) are west of the
MAR; (2) are aligned north-south, which is parallel to the MAR and nearly perpendicular to the alignment of the other Azorean islands; (3) have no record of significant historical seismicity; and (4) are subjects of few geophysical surveys.

Nonetheless, the results of several studies (Serughetti and Rocha, 1968; Krause and Watkins, 1970; Blakely, 1974; Azevedo, 1988, 1990; Azevedo et al., 1991; Bastos et al., 1993; Freire Luís et al., 1994; Azevedo and Ferreira, 1995; Baptista et al., 1999; Azevedo, 1999; Azevedo and Ferreira, 1999) support the following observation about Flores and Corvo volcanotectonic setting:

- Both islands are high subaerial parts of a single large mostly submarine edifice, built on a 9.0 to $10.0 \mathrm{Ma}$ oceanic crust (Blakely, 1974; Needham and Francheteau, 1974; Freire Luís et al., 1994).

- The tectonic setting and volcanic construction of both islands are likely related to the geodynamics of the MAR and associated transform faults. However, this inferred that structural control is clearly less evident than those for the central and eastern Azorean islands.

- A westward displacement of Corvo from Flores at about $1 \mathrm{~cm} /$ year (Baptista et al., 1999), together with the near-linear E-W north and south coastlines of 
Flores, reflect structural control by MAR transform faults, both in the past and at present.

- The main tectonic lineaments on Flores island are sinistral strike-slip $\mathrm{N} 30-40^{\circ} \mathrm{W}$ and normal N20$30^{\circ} \mathrm{E}$ faults (Azevedo, 1999) (Fig. 3). The N-S structural alignment emphasized in Forjaz (1988) has a clear secondary expression on the island subaerial domains.

- Development of important vertical tectonic movement affecting the crustal region of Flores Island since $1 \mathrm{Ma}$ ago. As a matter of fact, it should be noted that a submerged island (in present-day it corre- sponds to a seamount at the depth of $450 \mathrm{~m}$ ) located $50 \mathrm{~km}$ westwards of Flores Island shows a tectonic evolution (Ryall et al., 1983) different than that for Flores (see Section 5); while in Flores uplift dominated, the seamount subsided at about the same rate, supporting the concept of an isostatic compensation between the two adjacent blocks of the oceanic crust.

The geochronological data (Table 1) confers to the Flores oldest subaerial lavas an age of about $2.2 \mathrm{Ma}$ (Azevedo, 1988; Azevedo et al., 1991), which means

Table 1

Radiometric ages and chronostratigraphy of volcanic rocks from Flores Island, Azores

\begin{tabular}{|c|c|c|c|c|c|c|c|}
\hline Sample & $\begin{array}{l}\text { Location } \\
\text { on Fig. } 3\end{array}$ & Lithology-Structure & $\begin{array}{l}\mathrm{K} \\
(\%)\end{array}$ & $\begin{array}{l}\mathrm{Ar}^{40} \mathrm{rad} . \\
\left({ }^{\mathrm{cc}} \mathrm{STP} / \mathrm{G} \cdot 10^{-8}\right)\end{array}$ & $\begin{array}{l}\mathrm{Ar}^{40} \text { atm. } \\
(\%)\end{array}$ & $\begin{array}{l}\text { Age } \\
\text { (M.a.) }\end{array}$ & $\begin{array}{l}\text { Volcanic } \\
\text { unit }\end{array}$ \\
\hline $1^{\mathrm{a}}$ & 1 & Carbonized wood & & & & $0.0029 \pm 0.0001$ & $\mathrm{UC3}$ \\
\hline $2^{\mathrm{a}}$ & 2 & Carbonized wood & & & & $0.0030 \pm 0.0001$ & \\
\hline $7-95^{b}$ & 3 & Basalt-Lava-flow & 1.28 & 1.089 & 96.84 & $0.23 \pm 0.12$ & $\mathrm{UC2}$ \\
\hline $6-95^{b}$ & 4 & Basalt-Lava-flow & 1.19 & 1.250 & 91.37 & $0.27 \pm 0.11$ & \\
\hline $31-88^{b}$ & 5 & Basalt-Lava-flow & 1.31 & 2.465 & 91.98 & $0.35 \pm 0.08$ & \\
\hline $2-95^{\mathrm{b}}$ & 6 & Basalt-Lava-flow & 1.44 & 2.899 & 80.23 & $0.40 \pm 0.08$ & \\
\hline FL29 ${ }^{c}$ & 7 & Mugearite-Lava-flow & 2.65 & 2.150 & 89.00 & $0.55 \pm 0.12$ & UC1 \\
\hline $246-87^{b}$ & 8 & Basalt-Lava-flow & 1.06 & 2.323 & 94.91 & $0.56 \pm 0.12$ & \\
\hline $75-81^{b}$ & 9 & Mugearite-Lava-flow & 3.24 & 6.968 & 82.07 & $0.57 \pm 0.13$ & \\
\hline $4-95^{\mathrm{b}}$ & 10 & Hawaiite-Lava-flow & 2.74 & 6.993 & 88.65 & $0.57 \pm 0.09$ & \\
\hline $123-85^{b}$ & 11 & Trachyte-Dike & 4.35 & 8.763 & 92.55 & $0.57 \pm 0.05$ & \\
\hline $178-86^{\mathrm{b}}$ & 12 & Basalt-Lava-flow & 1.09 & 0.175 & 98.75 & $0.58 \pm 0.16$ & \\
\hline $18-81^{\mathrm{b}}$ & 13 & Trachyte-Dike & 4.33 & 9.851 & 71.86 & $0.59 \pm 0.05$ & \\
\hline $179-86^{\mathrm{b}}$ & 14 & Basalt-Lava-flow & 1.65 & 3.788 & 93.23 & $0.59 \pm 0.05$ & \\
\hline $8-95^{b}$ & 15 & Hawaiite-Lava-flow & 2.35 & 5.405 & 65.12 & $0.59 \pm 0.08$ & \\
\hline FL8 ${ }^{\mathrm{c}}$ & 16 & Mugearite-Lava-flow & 1.93 & 1.700 & 79.00 & $0.61 \pm 0.09$ & \\
\hline $150-86^{b}$ & 17 & Basalt-Lava-flow & 0.72 & 1.838 & 90.38 & $0.62 \pm 0.48$ & \\
\hline FL22 ${ }^{c}$ & 18 & Trachyte-Lava-flow & 4.47 & 4.090 & 60.00 & $0.62 \pm 0.05$ & \\
\hline $118-85^{b}$ & 19 & Hawaiite-Dike & 2.16 & 5.877 & 89.57 & $0.64 \pm 0.05$ & \\
\hline $153-86^{b}$ & 20 & Basalt-Lava-flow & 0.88 & 2.198 & 92.94 & $0.64 \pm 0.28$ & \\
\hline $183-86^{\mathrm{b}}$ & 21 & Basalt-Lava-flow & 1.23 & 0.186 & 99.66 & $0.64 \pm 0.24$ & \\
\hline $140-85^{b}$ & 22 & Hawaiite-Dike & 2.66 & 6.812 & 86.27 & $0.66 \pm 0.03$ & \\
\hline $245-87^{\mathrm{b}}$ & 23 & Basalt-Lava-flow & 1.59 & 3.507 & 91.08 & $0.74 \pm 0.15$ & $\mathrm{BC} 1$ \\
\hline $21-88^{b}$ & 24 & Hawaiite-Lava-flow & 2.39 & 9.390 & 81.89 & $0.86 \pm 0.04$ & \\
\hline $134-85^{b}$ & 25 & Basalt-Lava-flow & 0.92 & 1.349 & 97.99 & $0.96 \pm 0.19$ & \\
\hline $146-85^{b}$ & 26 & Basalt-Lava-flow & 1.58 & 7.573 & 95.85 & $0.97 \pm 0.32$ & \\
\hline $22-81^{b}$ & 27 & Mugearite-Dike & 3.09 & 12.012 & 71.54 & $0.98 \pm 0.04$ & \\
\hline $176-86^{b}$ & 28 & Basalt-Lava-flow & 1.70 & 4.410 & 87.82 & $1.01 \pm 0.08$ & \\
\hline $167-86^{\mathrm{b}}$ & 29 & Basalt/Hawaiite-Lava-flow & 1.84 & 6.289 & 91.98 & $1.53 \pm 0.07$ & $\mathrm{BC} 2$ \\
\hline $16-81^{b}$ & 30 & B-Neck & 1.53 & 2.590 & 98.16 & $1.57 \pm 0.45$ & \\
\hline $201-86^{b}$ & 31 & Basalt/Hawaiite-Lava-flow & 1.81 & 11.866 & 73.34 & $1.79 \pm 0.05$ & \\
\hline $202-86^{b}$ & 32 & Hawaiite-Lava-flow & 2.11 & 16.611 & 81.26 & $1.88 \pm 0.67$ & \\
\hline $226-87^{b}$ & 33 & Basalt/Hawaiite-Lava-flow & 1.85 & 12.890 & 77.70 & $1.96 \pm 0.06$ & \\
\hline $128-85^{b}$ & 34 & Basalt-Lava-flow & 0.44 & -0.708 & 99.96 & $2.04 \pm 0.79$ & \\
\hline $233-87^{b}$ & 35 & Hawaiite-Lava-flow & 2.00 & 15.131 & 90.56 & $2.11 \pm 0.62$ & \\
\hline $93-81^{b}$ & 36 & Basalt-Lava-flow & 1.65 & 15.423 & 71.73 & $2.16 \pm 0.16$ & \\
\hline
\end{tabular}

${ }^{a} \mathrm{C}^{14}$ determinations from Morisseau (1985).

b K/Ar ages from Azevedo et al. $(1986,1991)$ and Azevedo (1990, 1999); the determinations were obtained in the Geochronological Laboratory, Coimbra University.

${ }^{\mathrm{c}} \mathrm{K} / \mathrm{Ar}$ ages from Ferraud et al. (1980). 
that only Santa Maria, S. Miguel, Terceira and Graciosa Islands have older subaerial formations (Fig. 1).

\section{Volcanic rocks and volcanostratigraphy}

As with the other Azorean Islands, the Flores volcanic activity has included different processes and eruptive styles and dominantly involved basaltic and hawaiitic lavas. However, differentiated products, such as mugearites, benmoreites and trachytes, are also reported (Zbyszewsky et al., 1968; Torre de Assunção et al., 1974; Morrisseau and Traineau, 1985; Azevedo, 1999).

Present-day outcrops on the island include products and structures of the subaerial volcanism as well as of the emergent and submarine eruptions. Accordingly, the volcanic lavas and deposits were grouped into two major Complexes (Azevedo et al., 1986):

(1) The Base volcanic Complex (BC), which includes all the products and structures that resulted from the submarine and emergent volcanism.

(2) The Upper volcanic Complex (UC), which includes all the volcanic products of the subaerial volcanic activity.

Geologic mapping at a scale of 1:15,000 (Azevedo, 1999 ) - supported by radiometric ages (K/Ar data from Ferraud et al., 1980; Azevedo et al., 1986; Azevedo, 1990; Azevedo et al., 1991; Azevedo, $1999 ;{ }^{14} \mathrm{C}$ data from Morrisseau and Traineau, 1985; Table 1) and by petrographic and geochemical data (Torre de Assunção et al., 1974; Azevedo, 1999, 2003) - allows us to subdivide both Complexes and define a relatively detailed volcanostratigraphy (Table 2).

The BC formations crop out along the lower levels of coastal or paleo-coastal cliffs (Fig. 3) and are subdivided into Base Complex 1 (BC1) and Base Complex 2 (BC2), of Plio-Pleistocene age. The $\mathrm{BC}$ rocks are mainly volcaniclastic deposits (a mixture of hyaloclastite and hydroclastite, as defined by Batiza and Wite, 2000) of breccias and tuffs; these show intensive and pervasive palagonitization, and a great variability in texture, dimension $(0.005$ to $1.5 \mathrm{~m})$, and shape of the clasts. Pyroclasts are more common in $\mathrm{BC} 1$ deposits and autoclasts prevail within $\mathrm{BC} 2$ formations. Massive structures and intensive lithification are very pervasive in the breccias. An incipient and sub-horizontal lamination in the tuff and stratification in the coarser deposits are common. Some basaltic or hawaiitic lavaflows (Fig. 2) are interbedded in the middle and upper breccias and tuffs (Azevedo, 1988).

The UC is subdivided into Upper Complex 1 (UC1), Upper Complex 2 (UC2) and Upper Complex 3 (UC3). The upper Unit (UC1) was formed between 0.66 and 0.55 Ma (Table 1) and consists of extensive and sometimes very thick lava flows alternating with subordinate pyroclastic deposits. The UC1 rocks evolved from basaltic to trachytic compositions (Fig. 2). The middle Unit (UC2), whose age ranges from 0.4 to $0.2 \mathrm{Ma}$, is composed of basaltic and hawaiitic lava flows (Fig. 2) and associated pyroclastic deposits. The

Table 2

Volcanostratigraphy of Flores Island (adapted from Azevedo, 1999)

\begin{tabular}{|c|c|c|c|}
\hline Group (complex) & Volcanic unit & Volcanic sub-unit & $\begin{array}{l}\text { Geochronology } \\
\text { (Ma) }\end{array}$ \\
\hline \multirow[t]{8}{*}{ Upper complex-UC } & \multirow[t]{2}{*}{ Upper-UC3 } & Phreatomagmatic deposits $-\mathrm{H}$ & 0.002 \\
\hline & & Strombolian scoria cones $-\mathrm{G}$ & 0.003 \\
\hline & \multirow[t]{2}{*}{ 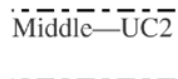 } & Intermediate hawaiites-F & 0.22 \\
\hline & & Intermediate basalts- $\mathrm{E}$ & 0.40 \\
\hline & \multirow[t]{4}{*}{ Lower- $\overline{\mathrm{UC}} \overline{\mathrm{l}} \overline{\mathrm{l}}$} & Inferior benmoreites-trachytes $=\mathrm{D}$ & 0.55 \\
\hline & & Inferior hawaiites-mugearites-C & \\
\hline & & Inferior basalts-hawaiites-B & \\
\hline & & Inferior basalts--A & 0.67 \\
\hline \multirow[t]{5}{*}{ Base complex-BC } & \multirow[t]{3}{*}{ Upper-BC1 } & Palagonitized breccias and tuffs- & $0.70-0.80$ \\
\hline & & Palagonitized basalts and hawaiites- $\mathrm{b}$ & $1.0-1.5$ \\
\hline & & Palagonitized breccias-c- & $\cong 1.8$ \\
\hline & \multirow[t]{2}{*}{ Lower- $\mathrm{BC} 2$} & Palagonitized basalts- & $2.0-2.2$ \\
\hline & & Palagonitized volcaniclastic deposits-e & \\
\hline
\end{tabular}

- - - Passage without volcanic quiescence and depositional unconformity.

- - - - - Passage with volcanic quiescence and/or depositional unconformity. 

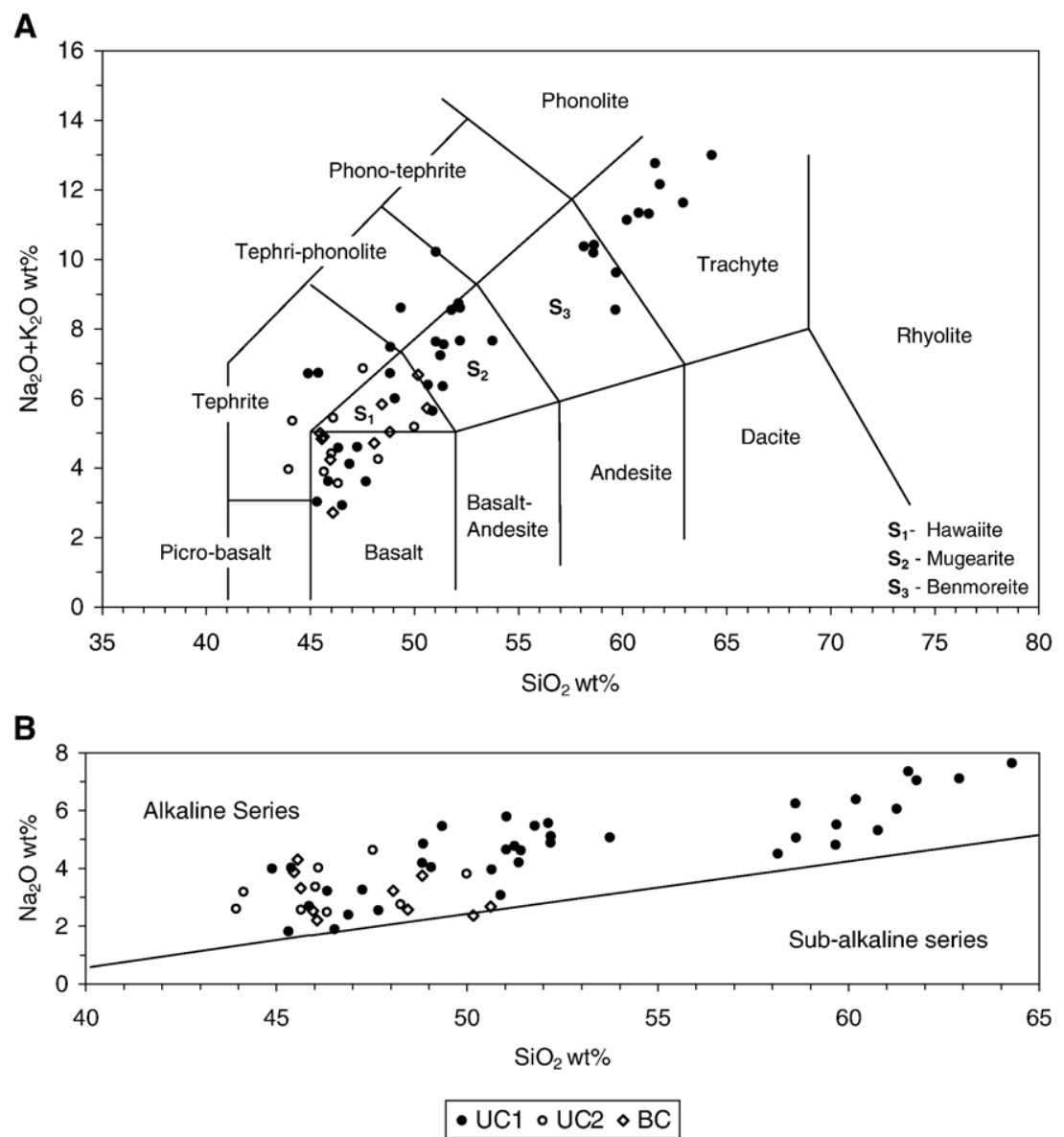

Fig. 2. Geochemical characterization of the lavas from Flores Island (geochemical data from Torre de Assunção et al., 1974; Azevedo, 1999); BC — Base volcanic Complex, UC - Upper volcanic Complex): (A) Total Alkali-Silica (TAS) classification (after Le Bas et al., 1986); (B) Silica-Na $2 \mathrm{O}$ variation diagram (after Middlemost, 1975).

upper Unit (UC3) was emplaced between 0.004 and $0.003 \mathrm{Ma}$ (Morrisseau and Traineau, 1985) and locally includes strombolian pyroclastic cones and a widespread ash mantle enriched with lithic clasts.

Periods of volcanic quiescence (or volcanic gaps) within the overall volcanic evolution of Flores Island (Table 2 and Fig. 5) are confirmed by field observations — not only by the absence of volcanic rocks, which in turn results in gaps in geochronological data, but also by the occurrence of pervasive paleosoils and/or depositional, lithological and structural unconformities within the volcanic sequences.

Taking into account the volcanostratigraphy, the petrochemical data from the effusive volcanic rocks of Flores Island demonstrate: (1) a great predominance of alkaline basalt and hawaiitic compositions; (2) a continuous petrological and geochemical sequence ranging from basalt to trachyte (Fig. 2A) recording a volcanogenetic differentiation process, which happened between about 0.75 and $0.40 \mathrm{Ma}$; (3) the subsequent volcanism (UC2 and UC3 eruptive episodes) involved exclusively basaltic and hawaiitic compositions; and (4) a pervasive sodic alkaline tendency (Fig. 2B).

\section{Volcanic setting and build-up processes}

The following reconstruction of volcanic history is mainly based on the interpretation of the primary lithological and structural facies of the eruptive products. However, the study of the secondary (or alteration) facies was particularly important for the interpretation of the $\mathrm{BC}$ volcanic setting.

\subsection{Base complex}

The diversity of products and structures present in the $\mathrm{BC}$ volcanic rocks points to a wide range of extrusive styles and depositional processes. Taking into account 
the scarcity of BC outcrops (Fig. 3) and the intensive secondary alteration (particularly of the volcaniclastic breccias and tuffs), the deciphering of their extrusional and depositional mechanisms is difficult.

The widely scattered occurrences of the BC outcrops (Fig. 3) argue for the existence of multiple feeder centres. The typically short length and thickness of most of the BC volcanic deposits suggest the development of small-to-medium scale volcanic centres. The coarse symmetrical distribution of the $\mathrm{BC}$ formations along a NNW-SSE axis suggests that structural lineaments with a similar trend possibly may have played an important role in the localization and evolution of the $\mathrm{BC}$ volcanic centres.

The occurrence of pillow lavas and the intensive palagonitization of much of the $\mathrm{BC}$ volcaniclastic deposits (hydroclastic deposits) indicate a regime of submarine and emergent volcanism. This corresponds to the proto-insular volcanism or the intermediate water/ shoaling stage, as defined by Schmidt and Schmincke (2000).

The very high percentage of volcaniclastic deposits within the BC Units indicates the involvement of highly efficient fragmentation processes. Moreover, the great variability in texture, dimension, and shape of the clasts supports the occurrence of both pyroclastic and autoclastic fragmentation, implying different degrees of lava-seawater interaction and consequently the occurrence of several eruptive styles. The predominance of pyroclastic deposits over autoclastic deposits and lava flows indicates a prevalence of explosive volcanism. Only two predominantly effusive periods are recorded, one by Sub-unit b of BC1 (Palagonitized Basalts and hawaiites) and another by Sub-unit d of BC2 (Palagonitized Basalts) (Table 2).

The morphometric and textural characteristics of the BC pyroclasts reflect explosive fragmentation from both magmatic and phreatomagmatic processes. The common presence of autoclasts and hyaloclastites within the $\mathrm{BC}$ breccias suggests an effective and widespread non-explosive fragmentation by autobrecciation (or flow fragmentation, as defined by Cas and Wright, 1987) and thermal granulation or quenching processes.

The stratigraphic sequence of the $\mathrm{BC}$ breccias and tuffs marks progression from submarine to emergent volcanic style, i.e., the transition from the intermediate to shoaling stage as defined by Schmidt and Schmincke (2000). Three stages of emergence are apparent: (1) the stage of dominantly nonexplosive fragmentation, reflecting deep submarine volcanism; this activity is recorded by the Sub-unit e of $\mathrm{BC} 2$ (Palagonitized volcaniclastic deposits, Table 2); (2) the stage of dominant hydroclastic explosive activity; this volcanism occurs below the volatile fragmentation depth (VFD, after Fisher and Schminke, 1984); and (3) the stage of the "sea-level" volcanism (or emergent volcanism) alternating between dry and temporary flooding of the vent (as defined by Kokelar, 1986; Cas and Wright, 1987); it corresponds to the most explosive $\mathrm{BC}$ volcanism, and it is recorded by the upper BC Sub-unit (Palagonitized breccias and tuffs, Table 2).

Moreover, lateral and vertical changes within the internal structure of the $\mathrm{BC}$ breccias and tuffs indicate several transportation-depositional mechanisms occurred within various depositional settings on the ocean floor. The considerable thickness (in some cases, about $100 \mathrm{~m}$ ) and the high incidence of massive internal structure for the majority of the $\mathrm{BC}$ deposits point to a quick succession of submarine volcaniclastic flows. The large amount of clasts supported by a palagonitized matrix suggests the development of submarine lahars and debris-flow processes (Azevedo, 1990; Azevedo et al., 1991). On the other hand, the volcaniclastic deposits without matrix-support reflect the progression of coarse grain-flows and collapses. The volcanic tuffs, and particularly the usual occurrence of cross bedding and double-grading structure, seem to be mainly the result of mudflows and turbidity currents (Azevedo, 1988).

The scarcity of pillow structures in the BC formations is a consequence of the low productivity of the effusive eruption, which is evidenced by the small thickness of the lava flows, and probably as well as the steep slope of the ocean floor.

\subsection{Upper complex}

The emplacement of Upper Complex (UC) began about $0.7 \mathrm{Ma}$ ago within a very restricted area (approximately inside the present-day island area) and it comprehended an eruptive process mainly based on a vertical overlapping of the volcanic events and products. The descriptions of the three UC Units volcanism follow.

\subsubsection{Upper complex 1 (UC1)}

The growth of this UC Unit generally involved volcanic processes with remarkable spatial and temporal continuity. However, there was a gradual evolution both in the volcanic activity and on the number and dimension of the feeder centres. Therefore, the deposition of UC1 may be divided into two sequential phases. 


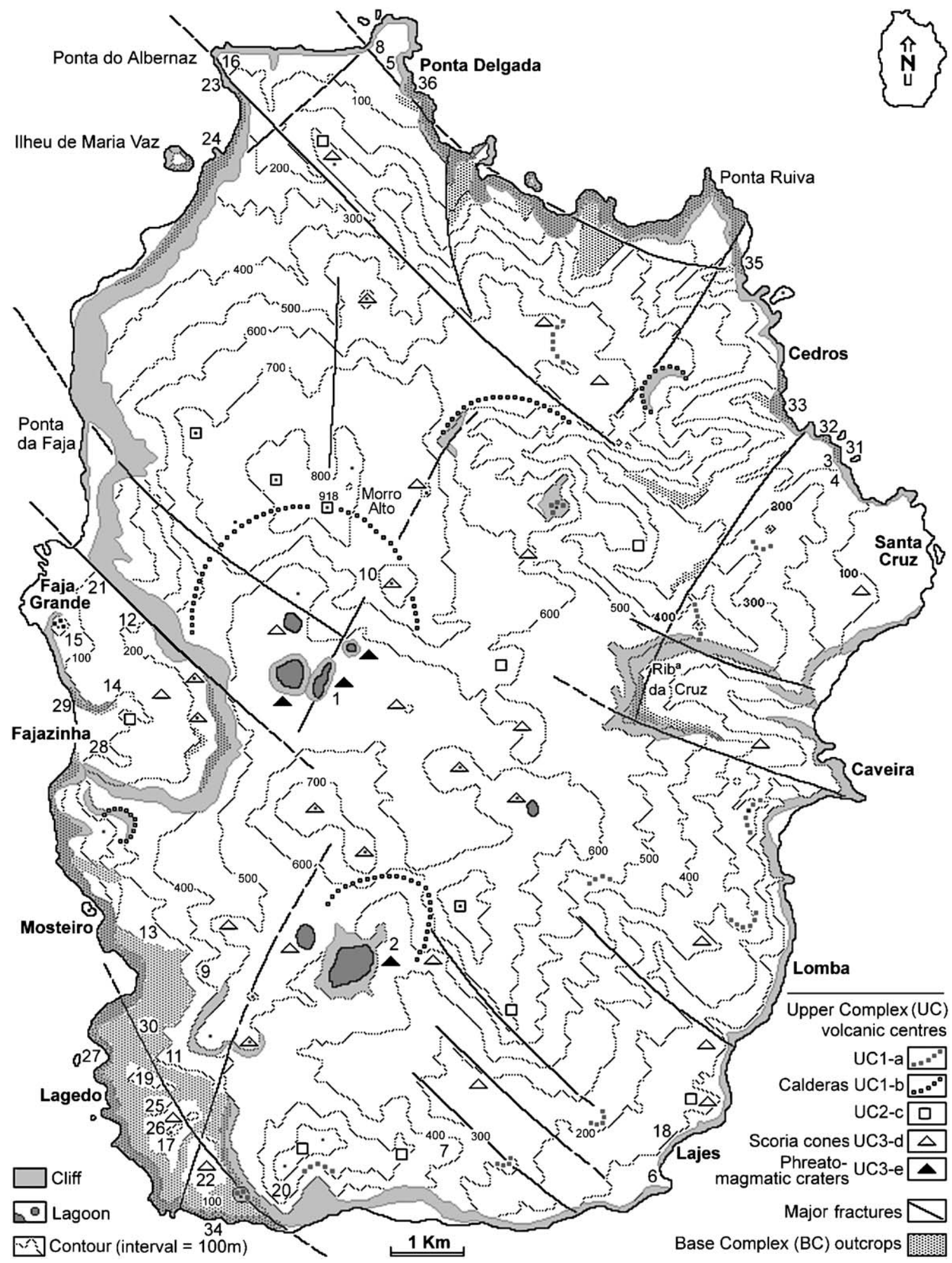

Fig. 3. Sketch map of Flores Island, showing: (1) Upper Complex major feeder centres (a, UC1 centres; b, UC1 affiliated calderas; c, UC2 centres; d, UC3 scoria cones; e, UC3 phreatomagmatic craters), (2) major fractures and (3) Base Complex outcrops. Numbers indicate dated lavas (see Table 1). 
Phase 1

\begin{tabular}{ll}
\hline Feeder centres & - Number and type: Two or three craters of large \\
& diameter (Figs. 3 and 4) \\
& - Morphology: High lateral extension; low to \\
& medium elevation \\
& - Localization: In the centre and on the NE and S \\
peripheries of the island \\
•
\end{tabular}

Phase 2

\begin{tabular}{|c|c|}
\hline Feeder centres & $\begin{array}{l}\text { - Number and dimension: Association of seven or } \\
\text { eight new small dimension craters to the } \\
\text { previous large centres (Fig. 3); intrusion of } \\
\text { several volcanic necks } \\
\text { - Localization: In the centre and along the } \\
\text { periphery of island }\end{array}$ \\
\hline Volcanic system & $\begin{array}{l}\text {-Polygenetic: Association of small-scale central- } \\
\text { volcanoes with asymmetric cones and volcanic } \\
\text { necks }\end{array}$ \\
\hline Volcanic activity & $\begin{array}{l}\text {-Explosivity: Gradual evolution from } 30 \% \text { to } \\
\text { about } 5 \% \\
\text {-Eruptive style: Progressive evolution from } \\
\text { hawaiian-strombolian to plinian activity }\end{array}$ \\
\hline Structural setting & $\begin{array}{l}\text {-Fracture systems: The same as for phase } 1 \\
\text { (fractures } \mathrm{N} 30^{\circ}-40^{\circ} \mathrm{W} \text { with } \mathrm{N} 20^{\circ}-30^{\circ} \mathrm{E} \text { ) in } \\
\text { association with small-scale fractures related to } \\
\text { the large volcanic centres }\end{array}$ \\
\hline Rock & -Sub-units C and D from UC1 (Table 2) \\
\hline Time interval & $\bullet 0.6$ to $0.55 \mathrm{Ma}$ (Table 1$)$ \\
\hline
\end{tabular}

These two volcanic phases, but particularly phase 1 , were undoubtedly the most productive of all the subaerial volcanism. The load imposed by the extrusion of considerable amounts of lava (ca. $70-80 \mathrm{~km}^{3}$, including eroded and preserved rocks) contributed to the specific crustal mosaics subsidence and the collapse of the larger craters and their surrounding domains, with the consequent formation of calderas with large diameters and small depths (Figs. 3 and 4).

\subsubsection{Upper complex 2 (UC2)}

The UC2 construction began after the consolidation of the subaerial eruptive building during UC1 volca- nism; therefore, the UC2 volcanic activity coincides with the cooling, alteration, weathering, and induration of the previously erupted lavas forming the island. The eruptive style, the number and dimension of the feeder centres and the quantity of the expelled material (ca. 10$15 \mathrm{~km}^{3}$ ) during UC2 were clearly distinct from those during the UC1 volcanism.

\begin{tabular}{|c|c|}
\hline Feeder centres & $\begin{array}{l}\text {-Number: About } 15 \text { (Fig. } 3 \text { ) } \\
\text {-Dimension: Changeable, but clearly subordinated } \\
\text { to the UC1 centres. } \\
\text { - Morphology: Mainly volcanic cones, sometimes } \\
\text { with deep flanks; fissural structures are rare } \\
\text {-Localization: Along the UC1 caldera borders and } \\
\text { on the island periphery }\end{array}$ \\
\hline Volcanic system & $\begin{array}{l}\text {-A group of small-scale strato-volcanoes in } \\
\text { association with monogenetic feeder centres }\end{array}$ \\
\hline Volcanic activity & $\begin{array}{l}\text {-Explosivity: } 40 \% \text { to } 50 \% \\
\text {-Eruptive style: Oscillating between strombolian } \\
\text { and hawaiian }\end{array}$ \\
\hline Structural setting & $\begin{array}{l}\text { - Fracture systems: A large number of eruptive } \\
\text { centres are aligned or rooted on the intersection of } \\
\mathrm{N} 40^{\circ} \mathrm{W}, \mathrm{N} 20^{\circ} \mathrm{W}, \mathrm{N} 20^{\circ}-30^{\circ} \mathrm{E} \text { and NS fractures; } \\
\text { other centres are associated to the calderas } \\
\text { collapse faults }\end{array}$ \\
\hline & -Sub-units E and F from UC2 (Table 2) \\
\hline Time & -Approximately between 0.4 and $0.23 \mathrm{Ma}$ (Table 1 \\
\hline
\end{tabular}

Because of their dominantly low viscosities, the emplacement of the UC2 lavas were largely topographically controlled. There are no strong indications (such as volcanic dikes and necks) of important intrusive activities and associated alteration phenomena during this eruptive period).

\subsubsection{Upper complex 3 (UC3)}

The UC3 products and structures exhibit a large contrast between the volcanic activity of this Unit and all preceding volcanism, and resulted from two distinct eruptive phases, which are recorded on the two UC3 sub-units (G-Strombolian scoria cones and H-Phreatomagmatic deposits):

Phase 1

\begin{tabular}{ll}
\hline Feeder centres & -Number: About 30 (Fig. 3) \\
& •Dimension and morphology: Small to medium \\
& scoria cones presenting usually sloppy flanks \\
& and short and smooth craters \\
& -Localization: Considerable concentration on the \\
& central area contrasting with the high dispersion \\
& on the insular periphery \\
Volcanic system & -Monogenetic cones \\
Volcanic activity & -Explosivity: $90 \%$ to $100 \%$ \\
& •Eruptive style: Strombolian, sometimes with a \\
& phreatomagmatic tendency \\
Structural setting & -The majority of the feeder centres are rooted on \\
& UC2 craters and vents
\end{tabular}




\begin{tabular}{ll} 
& $\bullet$ The other volcanic centres are associated to \\
& $\mathrm{N} 20^{\circ} \mathrm{E}$ fractures \\
Rock record & $\bullet$ Sub-unit G from UC3 (Table 2). \\
Time interval & $\bullet$ Close to $0.003 \mathrm{Ma}$ \\
\hline
\end{tabular}

Phase 2

\begin{tabular}{ll}
\hline Feeder centres & $\bullet$ Number: 4 centres (3 with individualized vents \\
& and 1 with 3 contiguous vents) (Fig. 3) \\
& $\bullet$ Dimension and morphology: Explosion craters \\
& expressing a great deepness, abrupt contours \\
and a diameters ranging from $150 \mathrm{~m}$ to ca. $1 \mathrm{~km}$ \\
\\
& $\bullet$ Localization: Inside the larger calderas from \\
& UC1 \\
Volcanic activity & $\bullet$ Explosivity: $100 \%$ \\
& $\bullet$ Eruptive style: Phreatic to phreatomagmatic \\
Structural setting & $\bullet$ Fracture systems: Three northern centres are \\
& associated to N25 $5^{\circ} \mathrm{E}$ and NS fractures; the \\
& southern centre is related to N40 $\mathrm{W}$ and \\
Rock record & N20 $20^{\circ}-25^{\circ} \mathrm{E}$ fractures \\
Time interval & $\bullet$ Sub-unit H from UC3 (Table 2). \\
\hline
\end{tabular}

The wide dispersion and substantial lateral continuity of the UC3 phreatomagmatic deposits indicate emplacement mechanisms involving high volcanic explosivity. The pyroclastic characteristics and, particularly, the fabric of the ash deposits fabric record the progression of tephra fall and ash-cloud surges, as well as the collapse of associated ash clouds.

The very young geologic age of these events $(\approx 0.002 \mathrm{Ma}$, in Morrisseau and Traineau, 1985) does not preclude a possible association with the present-day, but currently dormant, volcanic systems.

\section{Volcanotectonic history}

Taking into account (1) the volcanostratigraphy, (2) the tectonostructural evidence, particularly those related to vertical crustal movements (uplifts and subsidences) of neo- or volcano-tectonic origin and (3) the sequence of the subaerial records of marine influence, such as epiclastic marine deposits, specific erosional morphologies, intensive palagonitization and abrupt changes in the volcanic primary lithofacies (Azevedo and Ferreira, 1999), it is possible to divide the volcanotectonic evolution of Flores Island since $1 \mathrm{Ma}$ ago in four major stages (Fig. 5).

\subsection{Stage 1 (1.0 to $0.55 \mathrm{Ma}$ )}

\subsubsection{Volcanic activity}

It was very intensive and of the emergent type, i.e., predominantly explosive and corresponding to the transition from the proto-island to the island-formation period (Azevedo et al., 1991).

\subsubsection{Crustal vertical movements}

During this stage, important tectono-volcanic uplift took place, with an amplitude exceeding $100 \mathrm{~m}$ (the association between this uplift and the contemporaneous regression of the sea-level is evidenced by the presentday outcrops of BC formations at $400 \mathrm{~m}$ a.s.l.). This uplift was obviously related to the ongoing intensive volcanism of this period, though it might have been supplemented by the isostatic compensation between two adjacent lithospheric blocks (Azevedo et al., 1991; Azevedo and Ferreira, 1999), i.e., between Flores and the seamount $50 \mathrm{~km}$ to the west referred by Ryall et al. (1983).

\subsection{Stage $2(0.55$ to $0.4 \mathrm{Ma})$}

\subsubsection{Volcanic activity}

Including the final eruptive phases of the $\mathrm{UC} 1$, the volcanic activity was characterised by the voluminous outpouring of lavas from two or three large volcanic centres. It was then followed by a long period of volcanic quiescence (0.5 to $0.4 \mathrm{Ma})$.

\subsubsection{Crustal vertical movements}

During this stage, the Stage-1 uplift process ceased and was followed by subsidence. The weight of the very large amounts of lava extruded during UC1 volcanism might explain the subsidence of the whole island and particularly the collapse of its central zone, with the consequent formation of volcanic calderas. Some stepped morphologies on NE coast of the island might be the result of subsidence along $\mathrm{N} 20^{\circ} \mathrm{E}$ and $\mathrm{N} 30-40^{\circ} \mathrm{W}$ up-and-down faulting throughout this stage.

\subsection{Stage $3(0.4$ to $0.2 \mathrm{Ma})$}

\subsubsection{Volcanic activity}

This is the last major eruptive episode of this island — the UC2 volcanism.

\subsubsection{Crustal movements}

No important vertical tectonic movements were registered throughout this stage. However, the development of a slight volcanic doming associated with the UC2 eruptive activity cannot be dismissed.

\subsection{Stage 4 (0.2 Ma until the present)}

\subsubsection{Volcanic activity}

Following a long volcanic quiescent period ( 0.2 to about $0.004 \mathrm{Ma}$ ), a brief but very explosive volcanic episode occurred (UC3 strombolian and phreatomagmatic volcanism $\approx 0.003 \mathrm{Ma}$ ). 


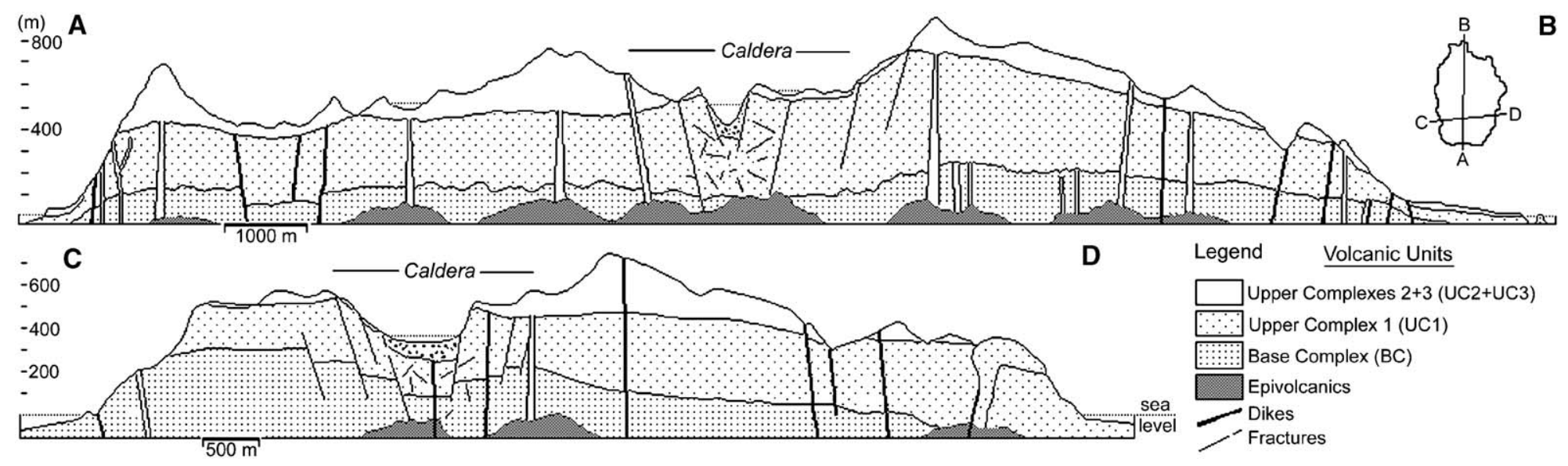

Fig. 4. Cross-sections illustrating the spatial settings of the volcanic Complexes and Units defined for Flores Island (after Azevedo, 1999). 


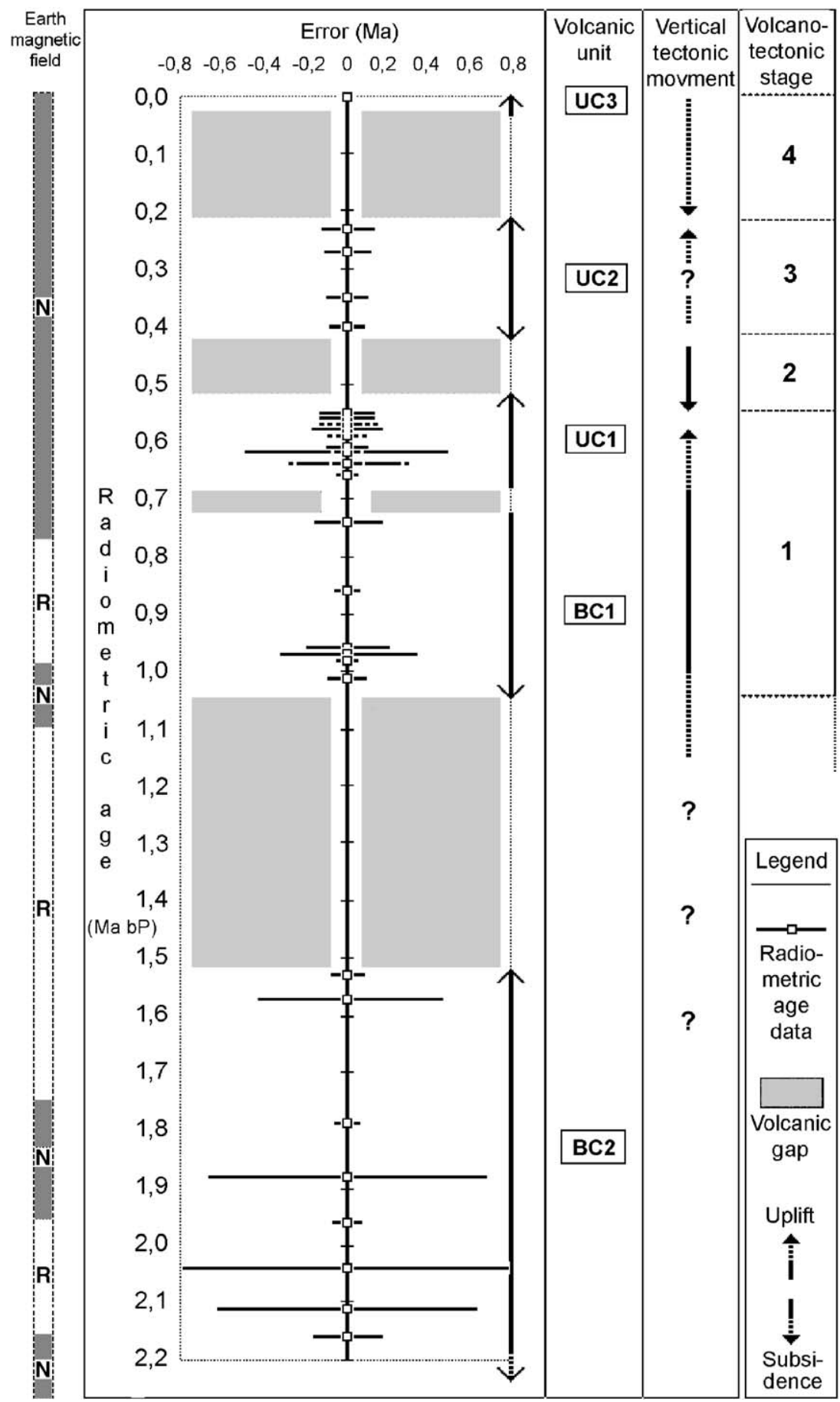

Fig. 5. Schematic representation of the radiometric ages, volcanic units, vertical tectonic movements and volcanostructural Stages defined for Flores Island (Earth's magnetic field polarity after Berggren et al., 1995).

\subsubsection{Crustal movements}

It is probable that the slow and gradual rate subsidence of the normally evolving oceanic crust resulting from thermal contraction (Sclater et al., 1971)
- had begun to affect the oceanic crust in Flores region, at least after the ending of the major steps of insular volcanism (UC2 and UC3). The post-insular phase might have started by then. 


\section{Acknowledgements}

The authors respectfully appreciate Professor José Ávila Martins (Azores University) for warmly opening for us in 1982 the gate into Azores Geology. We also give special thanks to all the Flores Islanders for their hospitality and to the decisive assistance of the reviewers.

\section{References}

Abdel-Monem, A., Fernandez, L.A., Boon, G.A., 1968. Pliocenepleistocene minimum $\mathrm{K}-\mathrm{Ar}$ ages of the older eruptive centers, Eastern Azores. Trans. Am. Geophys. Union 49 (1), 363.

Abdel-Monem, A., Fernandez, L.A., Boon, G.A., 1975. K-Ar ages from the eastern Azores group (Santa Maria, S. Miguel and the Formigas Islands). Lithos 8, 247-254.

Azevedo, J.M.M., 1988. Depósitos Vulcanoclásticos Submarinos. MSc Thesis. FCTUC, Coimbra University, Portugal. 240 pp.

Azevedo, J.M.M., 1990. Os depósitos vulcanoclásticos submarinos do Complexo de Base SW da ilha das Flores: estrutura e ambiente de formação. Mem. Not., Publ. Mus. Lab. Mineral. Geol. Univ. Coimbra, Portugal 109, 35-63.

Azevedo, J.M.M., 1999. Geologia e Hidrogeologia da Ilha das Flores, Açores. Ph D Thesis. FCTUC, Coimbra University, Portugal, Volumes I and II. 403 pp.

Azevedo, J.M.M., 2003. Petroquímica dos vulcanitos da Ilha das Flores, Açores. Proceedings of the IV Congresso Ibérico de Geoquímica, Coimbra University, Portugal. 3 pp.

Azevedo, J.M.M., Ferreira, M.P., 1995. As grandes Formações Vulcânicas da ilha das Flores, Açores. Proceedings do IV Congresso Nacional de Geologia, M.L.M.G. Universidade do Porto. 3 pp.

Azevedo, J.M.M., Ferreira, M.P., 1999. Volcanic gaps and subaerial records of palaeo-sea-levels on Flores Island (Azores): tectonic and morphological implications. J. Geodyn. 28, 117-129.

Azevedo, J.M.M., Ferreira, M.P., Martins, J.A., 1986. O Complexo de Base na Ilha das Flores, Açores. Mem. Not., Publ. Mus. Lab. Mineral. Geol. Univ. Coimbra, Portugal 101, 55-71.

Azevedo, J.M.M., Ferreira, M.P., Martins, J.A., 1991. The emergent volcanism of Flores Island, Azores, (Portugal). Arquipél., Ciênc. Nat., Azores Univ., Portugal 9, 37-46.

Azevedo, J.M.M., Dias, J.L.F., Alves, E.I., 2003. Contributo para a interpretação vulcanostrutural da ilha do Corvo, Açores. Proceedings of the VI Congresso Nacional de Geologia, FCT. Universidade Nova de Lisboa, Portugal. 4 pp.

Baptista, P., Osório, J., Bastos, L., Fernandes, R., Borges, F.S., 1999. Aplicação de técnicas geodésicas ao estudo do comportamento geodinâmico actual da Junção Tripla dos Açores. GEOlogos 5, $1-12$.

Bastos, L., Osório, J., Hein, G., Landau, H., 1993. Analysis of baseline repeatabilities in GPS network in the area of the Azores Triple Junction. Proceedings of the CRCM, vol. 93. Kobe, pp. 157-162. December 6-11.

Batiza, R., Wite, J.D.L., 2000. Submarine lavas and hyaloclastite. In: Sigurdsson, H. (Ed.), Encyclopedia of Volcanoes. Academic Press. $1417 \mathrm{pp}$.

Berggren, W.A., Kent, D.V., Aubry, M.P., Hardenbol, J., 1995. SEPM Spec. Publ. 54 (386 pp.)

Blakely, R., 1974. Geomagnetic reversal and crustal spreading rate during the Miocene. J. Geophys. Res. 79, 2979-2985.
Buforn, E., Udías, A., Colombás, M.A., 1987. Seismicity source mechanisms and tectonics of the Azores-Gibraltar plate boundary. Tectonophysics 152, 89-118.

Cas, R.A.F., Wright, J.V., 1987. Volcanic successions: modern and ancient. A Geological Approach to Processes, Products and Successions. Allen \& Unwin Ltd., London. 513 pp.

Feraud, G., Schmincke, H.U., Lietz, J., Gostaud, J., Pritchard, G., Bleil, U., 1984. New K-Ar ages, chemical analyses and magnetic data of rocks from the islands of Santa Maria (Azores), Porto Santo (Madeira archipelago) and Gran Canaria (Canary Islands). Arquipél., Rev. Univ. Açores (Sér, Ciên. Nat.) $5,213-240$.

Ferraud, G., Kaneoka, I., Allègre, J.C., 1980. K/Ar ages and stress pattern in Azores: geodinamic implications. Earth Planet. Sci. Lett. 46, 275-286.

Ferreira, M.P., Martins, J.A., 1983. Estudos de inversões paleomagnéticas na Ilha Terceira, Açores. Proceedings of the I Congr. Nac. Geologia. Aveiro. Portugal. 4 pp.

Fisher, R.V., Schminke, H.U., 1984. Pyroclastic Rocks. SpringerVerlag, Berlin. 472 pp.

Forjaz, V.H., 1988. Azores study tour. Field trip guide. Seminar on the prediction of earthquakes. Econ. Comm. for Europe-UN, Lisbon. $26 \mathrm{pp}$.

Freire Luís, J., Miranda, J.M., Galdeano, A., Patriat, P., Rossignol, J.C., Mendes Victor, L.A., 1994. The Azores triple junction evolution since $10 \mathrm{Ma}$. From an aeromagnetic survey of the mid-Atlantic Ridge. Earth Planet. Sci. Lett. 125, 439-459.

Hirn, A., Haessler, H., Hoang Trong, P., Wittlinger, P., Mendes Victor, L.A., 1980. Aftershock sequence of the January 1st 1980 earthquake and present-day tectonics in the Azores. Geophys. Res. Lett. 7, 501-504.

Kokelar, P., 1986. Magma-water interaction in subaqueous and emergent basaltic volcanism. Bull. Volcanol. 48 (5), 275-291.

Krause, D.C., Watkins, N.D., 1970. North Atlantic crustal genesis in the vicinity of the Azores. Geophys. J. R. Astron. Soc. 19, 261-283.

Le Bas, M.J., Le Maitre, R.W., Streckeisen, A., Zanettin, B., 1986. A chemical classification of volcanic rocks based on the Total Alkali-Silica Diagram. J. Petrol. 27 (3), 745-750.

Machado, F., Quintino, J., Monteiro, J.H., 1972. Geology of the Azores and the mid-Atlantic rift. Proceedings of the 24th Int. Geol. Congr., vol. 3, pp. 134-142.

Machado, F., Reis, P., Silveira, E., 1983. Sobre a profundidade de focos sísmicos no Atlântico Norte. Personal Comunication to $1^{\circ}$ Congr. Nac. Geol., Aveiro, Portugal.

Madeira, J., 1998. Estudos de neotectónica nas ilhas do Faial, Pico e S. Jorge: Uma Contribuição para o Conhecimento Geodinâmico da Junção Tripla dos Açores. - Ph D Thesis. Lisbon University, Portugal.

Madeira, J., Ribeiro, A., 1990. Geodynamic models for the Azores triple junction: a contribution from tectonics. Tectonophysics 184 , 405-415.

Madeira, J., Ribeiro, A., 1992. O regime tectónico nos Açores. Proceedings of the Encontro dos 10 anos após o sismo dos Açores de 1.Jan.1980, Angra do Heroísmo, 2-5/Out./1990. 10 pp.

McKenzie, D., 1972. Active tectonics of the Mediterranean Region. Geophys. J. R. Astron. Soc. 30, 109-185.

Middlemost, E.A.K., 1975. The basalt clan. Earth-Sci. Rev. 11, 337-364.

Morisseau, M., 1985. Études des enclaves lithiques hydrothermalisees liées aux eruptions hydromagmatiques. Examples des Azores: 
Flores et Faial. - BRGM-AFME. Institute Mixte de Recherches Géothermiques.

Morrisseau, M., Traineau, H., 1985. Mise en évidence d'une activité hydromagmatique holocène sue l'île de Flores (Açores). C.R. Acad. Sc. Paris, t. 301, Série II 18, 1309-1314.

Needham, H.D., Francheteau, J., 1974. Some characteristics of the rift valley in the Atlantic Ocean near $36^{\circ} 48^{\prime}$ North. Earth Planet. Sci. Lett. 22, 29-43.

Nunes, J.C., 1999. A actividade vulcânica na ilha do Pico do Plistocénico Superior ao Holocénico: mecanismo eruptivo e hazard vulcânico. - Ph D Thesis. Azores University, Portugal. 357 pp.

Ryall, P., Blanchard, M.C., Medioli, F., 1983. A subsided island west of Flores. Can. J. Earth Sci. 20, 764-775.

Schmidt, R., Schmincke, H.-U., 2000. Seamounts and island building. In: Sigurdsson, H. (Ed.), Encyclopedia of Volcanoes. Academic Press. 1417 pp.

Sclater, J.G., Anderson, R.N., Bell, M.L., 1971. The elevation of ridges and the evolution of the central eastern Pacific. J. Geophys. Res. 76, 7888-7915.
Searle, R., 1980. Tectonic pattern of the spreading centre and triple junction. Earth Planet. Sci. Lett. 51, 415-434.

Serughetti, J., Rocha, A., 1968. Études paleomagnetiques de quelques lavas de l'Ile de Flores. C. R. Hebd. Séances Acad. Sci., Série B 267, 1185-1188.

Torre de Assunção, C.F., Canilho, M.H., Canêlhas, S., 1974. Un aperçu sur la pétrografie éruptive des Açores (contributiones portugueses). Rev. Fac. Ciênc. Lisboa, Univ. Lisboa 14/1, 77-117.

Walker, G.P.L., 2000. Basaltic volcanoes and volcanic systems. In: Sigurdsson, H. (Ed.), Encyclopedia of Volcanoes. Academic Press. $1417 \mathrm{pp}$.

White, W.M., Schilling, J.-G., Hart, S.R., 1976. Evidence for the Azores mantle plume from strontion isotope geochemistry of Central North Atlantic. Nature 263, 659-663.

Zbyszewsky, G., Medeiros, C., Ferreira, V., Assunção, C.T., 1968. Carta Geológica de Portugal. Ilha das Flores. Serv. Geol. Port. $34 \mathrm{pp}$. 